\title{
Lazaroa
}

\section{The relationship between vegetation and modern pollen assemblages on Mount Paggeo (NE Greece)}

\author{
Arthur Glais ${ }^{1}$, Aristotelis C. Papageorgiou ${ }^{2}$, Ioannis Tsiripidis ${ }^{3}$, Daniel Abel-Schaad ${ }^{4}$, José Antonio \\ López-Sáez ${ }^{4} \&$ Laurent Lespez ${ }^{5}$
}

Received: 29 September 2016 / Accepted: 14 October 2016

\begin{abstract}
In this study, we investigated the relationship between vegetation and modern-pollen rain along the elevational gradient of Mount Paggeo. We apply multivariate data analysis to assess the relationship between vegetation and modern-pollen rain and quantify the representativeness of forest zones. This study represents the first statistical analysis of pollen-vegetation relationship along an elevational gradient in Greece. Hence, this paper improves confidence in interpretation of palynological records from north-eastern Greece and may refine past climate reconstructions for a more accurate comparison of data and modelling. Numerical classification and ordination were performed on pollen data to assess differences among plant communities that beech (Fagus sylvatica) dominates or co-dominates. The results show a strong relationship between altitude, arboreal cover, human impact and variations in pollen and nonpollen palynomorph taxa percentages.
\end{abstract}

Keywords: Fagus sylvatica; Mount Paggeo; NE Greece; Palynology; Phytosociology; Multivariate Analyses.

\section{[es] Relación entre la vegetación y la lluvia polínica actual en el Monte Paggeo (NE Grecia)}

Resumen. En este trabajo se investiga la relación existente entre la vegetación y la lluvia polínica actual a través de un gradiente altitudinal en el Monte Paggeo. Se aplican análisis multivariantes para evaluar la relación entre la vegetación y análogos polínicos modernos y cuantificar la representatividad de las zonas forestales. Este estudio representa el primer análisis estadístico de la relación entre polen y vegetación a lo largo de un gradiente altitudinal en Grecia. Por lo tanto, supone una contribución notable para interpretar más fielmente los registros palinológicos fósiles del noreste de Grecia y refinar las reconstrucciones paleoclimáticas y la modelización. La clasificación numérica y la ordenación fueron realizadas sobre los datos polínicos para delimitar posibles similitudes entre las comunidades vegetales dominadas o codominadas por el haya (Fagus sylvatica) en el Monte Paggeo. Los resultados muestran una fuerte relación entre la altitud, la cobertura arbórea, la presión antrópica y las variaciones en los porcentajes de taxones polínicos y no polínicos.

Palabras clave: Fagus sylvatica; Monte Paggeo; NE Grecia; Palinología; Fitosociología; análisis multivariantes.

\section{Introduction}

The southern regions of Europe are generally 2004; Médail \& Diadema, 2009). The populaaccepted as refugial areas, where most tree tions of trees, Fagus sylvatica among others,

\footnotetext{
Normandy University, UNICAEN, CNRS, LETG, F-14000 Caen, France. E-mail: arthur.glais@unicaen.fr

Forest Genetics Laboratory. Department of Forestry, Environment and Natural Resources, Democritus University of Thrace. Pantazidou 193, GR-68200 Orestiada, Greece. E-mail: apapage@fmenr.duth.gr

3 Department of Botany, School of Biology, Aristotle University of Thessaloniki, GR-54124 Thessaloniki, Greece. E-mail: tsiripid@bio.auth.gr

4 Grupo de Investigación Arqueobiología, Instituto de Historia, CCHS-CSIC, Albasanz 26-28, E-28037 Madrid, España-Spain. Email: dabe1222@hotmail.com, joseantonio.lopez@cchs.csic.es

5 LGP-UMR 8591 CNRS, Université de Paris Est-Créteil, 1 place Aristide Briand, F-92195 Meudon Cedex, France. E-mail: laurent.lespez@u-pec.fr
} 
which currently exist in refugial areas, have a relic nature and have maintained part of their species variation, which was not greatly disturbed by the influence of the Pleistocene glaciations (Hazler \& al., 1997; Tzedakis \& al., 2002; López-Merino \& al., 2008).

Fagus sylvatica is a strictly montane species in southern Europe (Bergmeier \& Dimopoulos, 2001). In Greece, it is restricted to the northern and central parts of the mainland, occurring in almost all the mountains in the floristic regions of north-eastern, northcentral and east-central Greece with an altitude above $1000 \mathrm{~m}$ asl, while it is fairly common in the northern Pindos floristic region, but it becomes scattered or even rare in the southern Pindos floristic region (Moulopoulos, 1965; Strid \& Tan, 1997). The southernmost occurrence of beech is located in the floristic region of Sterea Ellas, on a mountain that is called after the Greek name of beech (i.e. Oxya). For instance, the mainland of Greece is a mountainous region and specifically eastern Greece is divided by many regular and interrupted mountain ranges (Strid, 1986). In this area, Pleistocene climatic fluctuations resulted in extensive changes in vegetation (Tzedakis \& $a l ., 2006)$, while the rugged terrain of the territory has led to endemic species in eastern continental Greece mostly occurring at moderate to high altitudes, because of the role of mountains as centres of speciation (Tsiripidis \& Athanasiadis, 2003; Georghiou \& Delipetrou, 2010).

The abovementioned facts have caused that the taxonomic history of the genus Fagus in Greece and in the whole of western Eurasia have been complicated and controversial (Papageorgiou \& al., 2008). The most accepted taxonomic classification suggests that one beech species exists in Eurasia (Fagus sylvatica) with two subspecies, subsp. sylvatica and subsp. orientalis (Denk \& al., 2002; Denk, 2003; Gailing \& von Wuehlisch, 2004); although other authors consider both as different species, establishing a contact area between their natural ranges in northern Greece and Bulgaria (Paule, 1995; Govaerts \& al., 2013), and the fact that $F$. sylvatica subsp. orientalis seems to be the ancestral subspecies (Vettori \& al., 2004; Paffetti \& al., 2007). Furthermore, morphological characters indicate that the southern Rhodope Mountains constitute a transitional zone between both subspecies (Tsiripidis \& Athanasiadis, 2003; Papageorgiou \& al., 2008).
Palaeobotanical and genetic data indicate the presence of beech refugia in the Balkan Peninsula during the last glaciations (Demesure \& al., 1996; Gömöry \& al., 1999; Comps \& al., 2001; Magri \& al., 2006; Hatziskakis \& al., 2009). Huntley \& Birks (1983) and Taberlet \& al. (1998) propose that the current distribution of beech in central Europe derives from the postglacial recolonization of populations originating mainly from the Balkan refugia. On the contrary, Magri \& al. (2006) and Magri (2008) argue that the main refugial areas, from where the recolonization to central and Western Europe occurred, were located close to the Alps in Slovenia and south-western France, and that the populations deriving from the Balkan Peninsula did not migrate to northern Europe.

In Bulgaria and Greece, data from pollen analyses indicate the existence of at least two main refugia: i) the Rhodope Mountains and ii) western Greece (Filipova-Marinova, 1995; Pott, 1997; Tzedakis \& al., 2013). Magri \& al. (2006) propose the existence of three refugia, one in western Greece (Epirus) and two in northern Greece and southern Bulgaria (eastern Macedonia and the Rhodope Mountains). The complex topography of the Balkan Peninsula, the interaction of several climate influences, and the discontinuous distribution of beech in Bulgaria and Greece, at different altitudes in several well-separated mountain areas, points towards the existence of heterogeneous environmental conditions putatively promoting complex recolonization and remigration patterns (Hatziskakis \& al., 2009, 2011).

The intensity and duration of human impacts on north-eastern Greece forests suggest also complex genetic responses. For instance, genetic drift due to fragmentation and conversion of land use, selection due to forest management practices, climate change and gene flow because of modified spatial distributions of trees (Rajendra \& al., 2014). Beech is wind-pollinated and monoecious with heavy fruits and limited seed dispersal (Piotti \& al., 2012). As a predominantly outcrossing tree species with efficient means of gene dispersal through pollen, it usually shows high genetic diversity within populations, but a rather low differentiation among populations (Vornam \& al., 2004; Magri \& al., 2006). In any case, both morphological traits and gene markers revealed the uniqueness of beech populations on the south-eastern 
side of Rhodope Mountains (Mt. Paggeo, eastern Macedonia, and NE Greece) at low elevations (Hatziskakis \& al., 2009). In fact, private haplotypes in this area are usually found at high frequencies in beech forests located in or near ravines, having a high spatial overlap with a relict vegetation type occurring in ecological conditions mainly found in ravines (Papageorgiou \& al., 2008, 2014). Furthermore, haplotypes originating from two more widespread beech lineages in Greece are also found on Mt. Paggeo, indicating a possible mixture of populations originating from a local refugium with populations from remote refugia that possibly migrated into the area after the last glaciations.

In north-eastern Greece, numerous pollen records provide important insights into the impact of climate variability and human activities on Mediterranean ecosystems (e.g.Willis, 1994; Tzedakis \& al., 2006; Glais \& al., 2016a, 2016b; Lespez \& al., 2016). However, the confident use of fossil pollen data to reconstruct vegetation and climate dynamics requires well-founded knowledge regarding the relationship between pollen deposition and modern-day vegetation, which is still deficient for large parts of Greece. In this way, modern pollen rain and vegetation inventory data within different vegetation types are essential keys for the interpretation of past vegetation from fossil pollen sequences and for palaeoecological reconstruction (López-Sáez \& al., 2013). In fact, the specific composition and characteristics of a forest understorey depend to a great extent on both past and present events, including the frequency and intensity of human disturbances (López-Sáez \& al., 2010).

In this paper, we study for the first time modern pollen samples from Mount Paggeo to discriminate Fagus sylvatica forest communities. To date few studies of modern pollen rain have been attempted in Greece (Hicks \& al., 2001; Gerasimidis \& al., 2006).

The mountain massif of Paggeo in northeastern Greece was chosen as the study area because: i) it is geomorphologically isolated from other mountains of the Greek southern Rhodope range (Eleftheriadis \& Koroneos, 2003) and 'island' type population of beech (Fagus sylvatica) grows on it; ii) beech forests cover a wide elevational range from 600 to $1800 \mathrm{~m}$ asl and occur in sites with different ecological conditions, resulting in a high diversity of beech forest plant communities (Papageorgiou \& al., 2014); and, iii) the geomorphological diversity of the mountain is high, and a deep gorge on its north-eastern slope offers suitable ecological conditions for the preservation of relict species or populations (Tzedakis \& al., 2002).

The main objectives of our study are (1) to explore how contemporary vegetation is depicted in surface pollen assemblages along a longitudinal transect on the Mount Paggeo, (2) to identify pollen indicators of Fagus sylvati$c a$ forest syntaxa, and, (3) to establish statistic relationships between pollen rain and vegetation patterns in order to use them for paleoecological reconstruction in future studies.

\section{Study area}

Mount Paggeo (Pangeon, Pangaion) is located in north-eastern Greece (eastern Macedonia), approximately $40 \mathrm{~km}$ from Kavala (Figure 1). Its highest peak has an elevation of $1956 \mathrm{~m}$ asl (Koutra peak). It is close to the coast of the Aegean Sea and spatially isolated from other mountains of north-eastern Greece with extensive beech forest vegetation (e.g. Menikio, Falakro and Rhodope) by the lowland areas located northwards.

According to the Köppen classification, the climate of the Mt. Paggeo belongs to the intermediate type Csa-Ssb, characterized as transitional from the Mediterranean to the continental climate (Balafoutis, 1977). The ombrothermic diagram (temperature-precipitation) of Kavala shows a 4-month dry period that extends from late May till late September and culminates in August when higher water deficit conditions are observed. 
Figure 1. Location of the study area (white square) in northeastern Greece (eastern Macedonia)

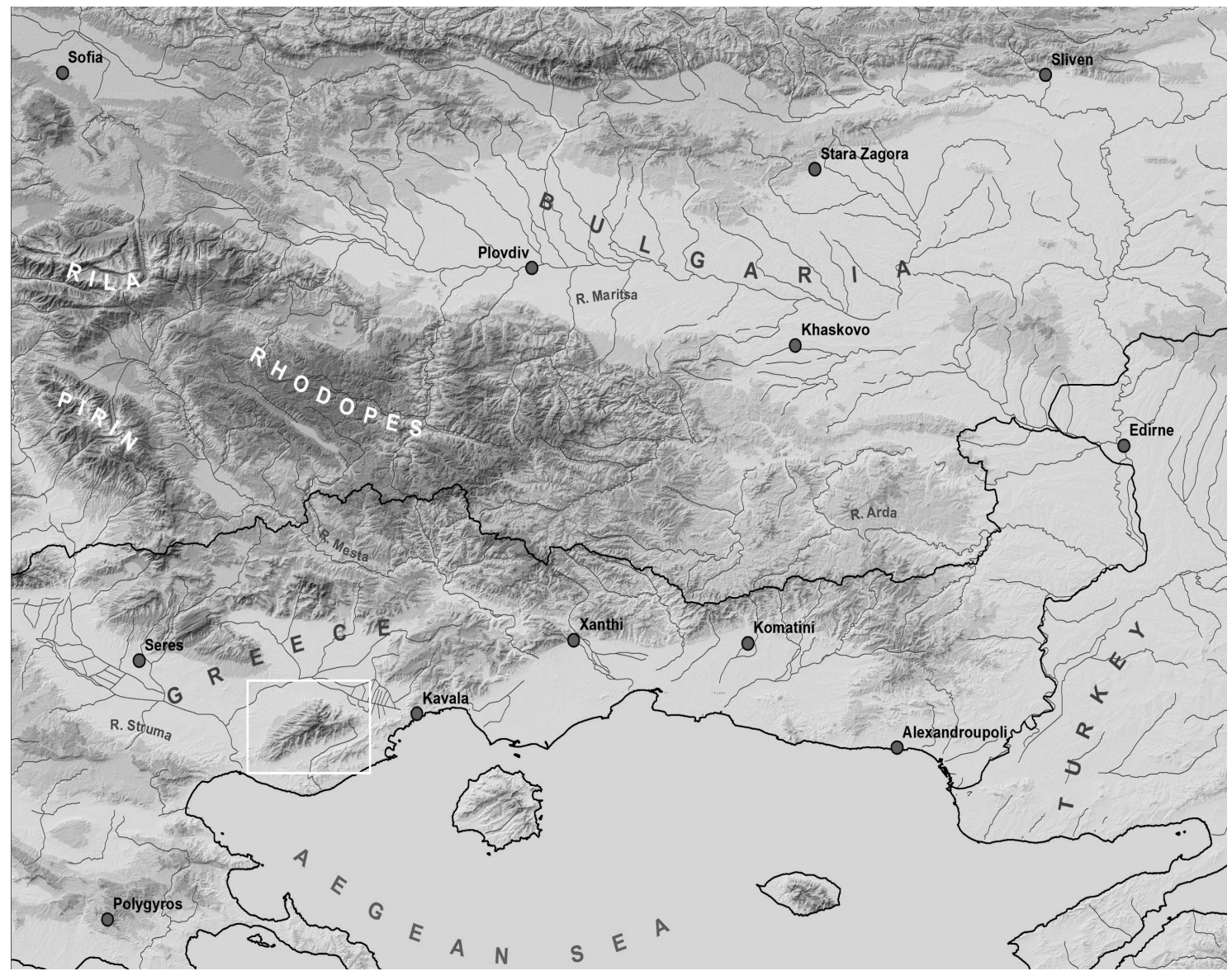

Mt. Pangeon region geologically belongs to the Western Rhodope Zone and forms a highly uplifted, dome-like, horst structure composed by metamorphic rocks of Palaeozoic-Mesozoic age, Oligocene magmatic rocks, and sedimentary rocks of Upper Miocene age to recent, and mainly consists of i) a lower relatively uniform sequence of schists and gneisses, ii) a middle sequence of intensively alternating bends of marbles, gneisses and amphibolites, and, iii) an upper thick marble zone; while granitoids are exposed in several erosion-windows in the form of relatively small separate intrusive bodies (Eliopoulos, 2000; Eleftheriadis \& Koroneos, 2003).

The vegetation of the Mount Paggeo presents a high diversity as a result of the mesoand microclimate as well as the substrate type differentiation. Additionally, human impact has affected significantly the vegetation. At lower altitudes (200-600 m asl), pseudomaquis dominated by Quercus coccifera are well developed, mainly in south exposed slopes and they can reach in some localities also higher altitudes (even $1000 \mathrm{~m}$ asl). These formations are also rich in Fraxinus ornus, Juniperus oxycedrus, Phillyrea latifolia, Carpinus orientalis, Quercus pubescens, Acer campestre, Arbutus unedo, Clematis flammula, Erica arborea, Crataegus monogyna and Syringa vulgaris. This vegetation is gradually replaced by deciduous shrublands at higher altitudes (700-900 m asl), mainly composed by Carpinus orientalis, Fraxinus ornus, Acer monspessulanum, Ligustrum vulgare, Lonicera etrusca, Cornus mas and Ostrya carpinifolia, although this sub-mediterranean vegetation is probably a result of human impact, overgrazing and forest fires (Tsiftsis \& al., 2007). Above, xerothermic sub-mediterranean deciduous oak forests occur, mainly dominated by Quercus frainetto, $Q$. pubescens and $Q$. petraea subsp. polycarpa in the northeastern slopes. Except oak, another deciduous 
broadleaved tree, Castanea sativa, forms scattered stands in the northern slopes of Mt. Paggeo, mostly mixed with Tilia tomentosa. This plant community corresponds to the Tilio tomentosae-Castanetum (Bergmeier \& Dimopoulos, 2008). Beech forests appear above the oak or the chesnut forests on gneissschist, marble, and, more rarely, on granite (Papageorgiou \& al., 2014), although in the lower altitudes they form mixed stands with oaks (Tsiripidis \& Athanasiadis, 2003).

On Mount Paggeo, beech forests come down to $600 \mathrm{~m}$ asl, while their upper limits are climbing up to $1800 \mathrm{~m}$ asl forming the timberline (Figures 2 and 3). Three plant communities of beech forest occur in the mountain and they are differentiated according the substrate and the altitude. Within beech forests occasionaly occur woody species such as Ilex aquifolium, Daphne laureola, Euonymus latifolius, Prunus cerasifera, Abies borisii-regis, Acer platanoides, A. hyrcanum, Quercus frainetto, $Q$. petraea subsp. polycarpa and
Betula pendula. Fagus sylvatica co-dominates also in another very special plant community. This is a community developed within the impressive ravine formed on the north-eastern slopes of Mt. Paggeo and hosting moistdemanding and some considerably rare species for Greece, such as Taxus baccata, Tilia platyphyllos, T. tomentosa, Ulmus glabra, Carpinus betulus, Acer platanoides and A. pseudoplatanus. This vegetation type can be classified within Tilio-Acerion and not in a syntaxon (i.e. alliance or association) representing beech forests. Above, timberline subalpine calcareous grasslands are welldeveloped (Karagiannakidou \& al., 2001), characterized by a diverse flora dominated by perennial grasses and other forbs such as Sesleria achtarovii, Asperula aristata, Dianthus petraeus, Festuca ovina agg., Carex halleriana, Festuca varia, Stipa pennata, Rostraria cristata, Vincetoxicum hirundinaria, Polygala nicaeensis, Scabiosa ochroleuca and others.

Figure 2. Map showing the surface pollen samples on the Mount Paggeo. White shadowed areas indicate the distribution of Fagus sylvatica forests.

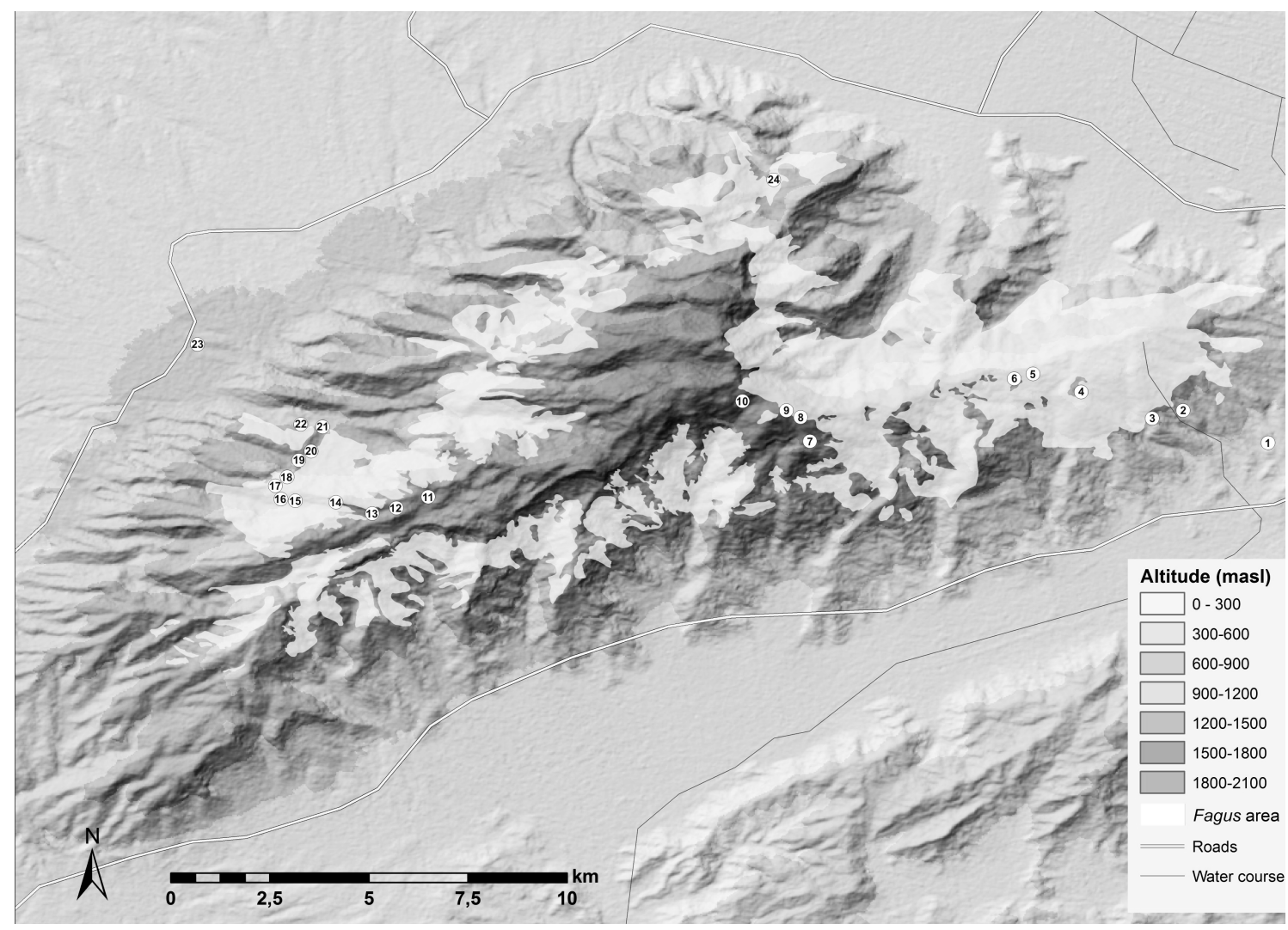


Table 1. Study sites and site characteristics for the 24 modern pollen surface samples from the Mount Paggeo. All the 4-digit codes of the habitats types given correspond to those included in the Annex I of Habitats Directive (92/43/EU), except the code of pseudomaquies (5350) which is a Greek national habitat code (Dafis \& al., 2001).

\begin{tabular}{|c|c|c|c|c|c|c|c|}
\hline Sample & Longitude & Latitude & $\begin{array}{l}\text { Altitude } \\
\text { (m asl) }\end{array}$ & $\begin{array}{l}\text { Tree } \\
\text { Cover }\end{array}$ & $\begin{array}{l}\text { Grazing } \\
\text { pressure }\end{array}$ & Vegetation type & $\begin{array}{c}\text { European } \\
\text { Habitat }\end{array}$ \\
\hline 1 & 24.234829 & 40.911263 & 220 & 5 & 1 & Pseudomaquis & 5350 \\
\hline 2 & 24.214323 & 40.918990 & 540 & 5 & 3 & Pseudomaquis & 5350 \\
\hline 3 & 24.203636 & 40.916898 & 645 & 4 & 0 & $\begin{array}{l}\text { Thermophilous } \\
\text { beech forests }\end{array}$ & 9280 \\
\hline 4 & 24.191348 & 40.919752 & 910 & 5 & 1 & $\begin{array}{l}\text { Thermophilous } \\
\text { beech forests }\end{array}$ & 9280 \\
\hline 5 & 24.173487 & 40.921004 & 1080 & 5 & 1 & $\begin{array}{l}\text { Acidophilous beech } \\
\text { forests }\end{array}$ & 9110 \\
\hline 6 & 24.167360 & 40.918644 & 1130 & 4 & 2 & $\begin{array}{l}\text { Acidophilous beech } \\
\text { forests }\end{array}$ & 9110 \\
\hline 7 & 24.119292 & 40.903053 & 1515 & 4 & 2 & $\begin{array}{l}\text { Pinus sylvestris } \\
\text { plantation }\end{array}$ & - \\
\hline 8 & 24.115510 & 40.909386 & 1595 & 5 & 2 & $\begin{array}{l}\text { Calcicolous beech } \\
\text { forests }\end{array}$ & 9150 \\
\hline 9 & 24.113200 & 40.910661 & 1610 & 1 & 4 & $\begin{array}{l}\text { Calcicolous beech } \\
\text { forests }\end{array}$ & 9150 \\
\hline 10 & 24.105875 & 40.911979 & 1632 & 0 & 4 & $\begin{array}{l}\text { Subalpine } \\
\text { calcareous } \\
\text { grasslands }\end{array}$ & 6170 \\
\hline 11 & 24.024530 & 40.888285 & 1340 & 0 & 4 & $\begin{array}{l}\text { Subalpine } \\
\text { calcareous } \\
\text { grasslands }\end{array}$ & 6170 \\
\hline 12 & 24.018957 & 40.885992 & 1310 & 0 & 1 & $\begin{array}{l}\text { Subalpine } \\
\text { calcareous } \\
\text { grasslands }\end{array}$ & 6170 \\
\hline 13 & 24.014451 & 40.886283 & 1260 & 3 & 0 & $\begin{array}{l}\text { Calcicolous beech } \\
\text { forests }\end{array}$ & 9150 \\
\hline 14 & 24.008898 & 40.887443 & 1165 & 5 & 2 & $\begin{array}{l}\text { Acidophilous beech } \\
\text { forests }\end{array}$ & 9110 \\
\hline 15 & 23.996790 & 40.892480 & 1005 & 5 & 1 & $\begin{array}{l}\text { Acidophilous beech } \\
\text { forests }\end{array}$ & 9110 \\
\hline 16 & 23.997663 & 40.894157 & 960 & 5 & 0 & $\begin{array}{l}\text { Calcicolous beech } \\
\text { forests }\end{array}$ & 9150 \\
\hline 17 & 23.999245 & 40.894121 & 945 & 5 & 0 & $\begin{array}{l}\text { Calcicolous beech } \\
\text { forests }\end{array}$ & 9150 \\
\hline 18 & 23.999110 & 40.895715 & 880 & 3 & 2 & $\begin{array}{l}\text { Calcicolous beech } \\
\text { forests }\end{array}$ & 9150 \\
\hline 19 & 24.001352 & 40.900582 & 750 & 5 & 1 & $\begin{array}{l}\text { Thermophilous } \\
\text { beech forests }\end{array}$ & 9280 \\
\hline 20 & 23.998842 & 40.904086 & 660 & 5 & 1 & $\begin{array}{l}\text { Thermophilous } \\
\text { beech forests }\end{array}$ & 9280 \\
\hline 21 & 23.998474 & 40.904905 & 615 & 4 & 1 & Pseudomaquis & 5350 \\
\hline 22 & 23.996628 & 40.907142 & 550 & 5 & 1 & Pseudomaquis & 5350 \\
\hline 23 & 23.973587 & 40.930175 & 320 & 2 & 3 & Pseudomaquis & 5350 \\
\hline 24 & 24.105463 & 40.963194 & 605 & 5 & 0 & Ravine forests & 9180 \\
\hline
\end{tabular}




\section{Material and Methods}

\section{Field methods - vegetation and pollen sampling}

Vegetation and pollen samples were collected in the spring and summer of 2014 and 2015 respectively at 24 locations on Mt. Paggeo (Figure 2). Sample locations were chosen to cover a variety of vegetation types, ranging from lowland scrub to the forested landscapes of the higher elevations, although the aim was mainly to analyse modern pollen rain in order to sample four plant communities dominated or co-dominated by Fagus sylvativa. Moss polsters samples were collected at each location to provide modern pollen data, with positional and altitudinal data recorded using a portable Juno 3D Trimble Ltd. Global Positioning System (GPS) device. Moss samples were collected over an area of approximately $100 \mathrm{~m}^{2}$ by taking multiple moss polsters from the concerned site to ensure an even representation (López-Sáez $\&$ al., 2013). The subsamples were sealed in plastic bags and mixed into one sample per site. Moss polsters are commonly used as surface samples for local modern pollen rain as it is assumed that they record an average of several years of pollen deposition and are considered as a good analogue of fossil pollen assemblages (López-Sáez \& al., 2015). In heterogeneous landscapes like Mt. Paggeo, relevant source areas of about 50$100 \mathrm{~m}$ from a sample location have been shown to properly reflect the local vegetation (Sugita, 1994). These sample locations were arrayed along a vegetation transect covering the full elevation range of the mountain. Table 1 lists the locations and gives a short description about each recorded site in the study region. A relevé of vegetation was also made at each sampling site. Two environmental variables were available for 24 sites (Table 1). Tree cover was graded on an ordinal scale from 0 to 5 at each sampling point $\left(100 \mathrm{~m}^{2}\right)$ as follows: $5(75-100 \%), 4(50-75 \%), 3$ (25$50 \%), 2(5-25 \%), 1(1-5 \%), 0(0 \%)$. Grazing pressure was estimated on a scale of 0 to 4 (Court-Picon \& al., 2006).

\section{Laboratory methods - pollen}

Moss polsters samples of approximately 10 $\mathrm{cm}^{3}$ were homogenized prior to extraction. The samples were sieved through $1 \mathrm{~mm}$ screens to remove larger particles (e.g., leaves, twigs, and gravel) and then processed following the standard protocol developed by Faegri \& Iversen (1989). Samples were stored in glycerol, mounted on microscope slides and examined with a Nikon Eclipse 50i lightmicroscope (Melville, NY, U.S.A.) to identify pollen and spores. Pollen generally was counted at 400x magnification, with more difficult identifications made under oil inmersion at 1000x magnification. Pollen grains and nonpollen palynomorphs (NPPs) were identified according to Moore \& al. (1991) and VAN GEEL (2001) at the lowest currently possible taxonomical level. "Type" groups of several taxa that are morphologically indistinguishable were used. Betulaceae and Corylaceae pollen taxa were palynologically identified according to Blackmore \& al. (2003). A minimum of 500 pollen grains were identified and counted for each sample. Pollen percentages were calculated excluding indeterminant pollen grains, hydro-hygrophytes taxa and spores, and presented as bars in a pollen percentage diagram. Tilia and TGView (Grimm, 1992) and CorelDraw software were used to plot the pollen diagrams (Figures 3 and 4). The terms 'local', 'extralocal', 'regional' and 'extraregional' used in the text refer to different pollen source areas according to Prentice (1985).

\section{Numerical analyses}

Although 90 pollen and spore taxa were identified in the surface samples, only palynomorph taxa present at $>1 \%$ were included in numerical analyses. These were performed on recalculated percentages after all modifications had been made, with the program IBM SPSS Statistics 21.

Hierarchical cluster analysis (HCA) was used as an exploratory tool to classify the pollen samples and the pollen taxa according to their dissimilarity. This method provides valuable means of revealing groupings within multivariate modern pollen data. HCA was performed using the matrix of the squared Euclidean distances and Ward's minimum variance method (Ward, 1963). The percentage values of each taxon were not transformed. The hierarchical relationships among clusters are illustrated by the dendrograms in Figures 5 and 6.

Data were processed (modern surface pollen samples) by ordination analysis to 
Figure 3. Percentage pollen diagram for trees and shrubs of the 24 surface samples on the Mount Paggeo and altitudinal vegetational gradient.

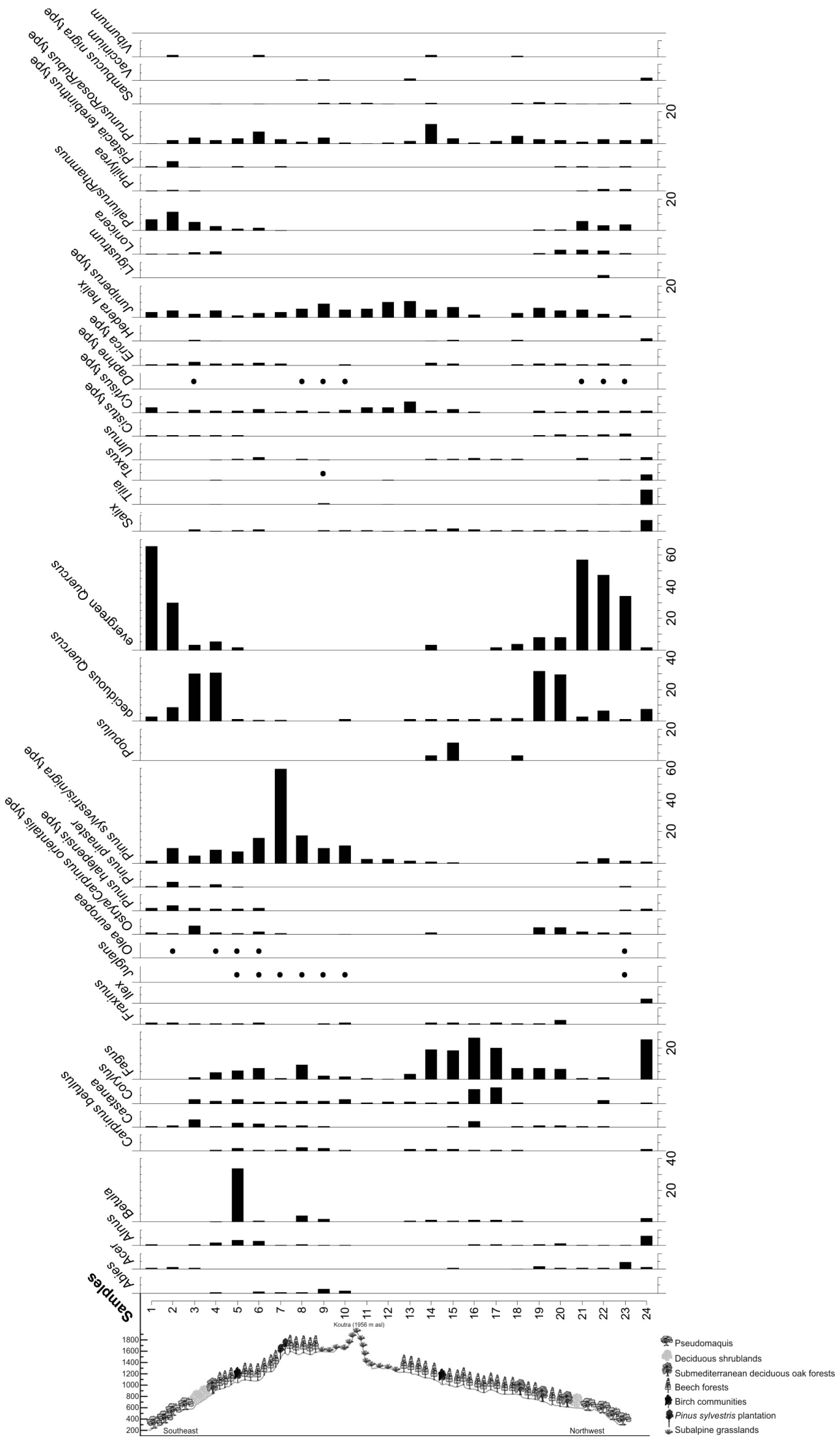


obtain more information about the data structure since these techniques are considered appropriate for assessing and displaying the relationship between pollen taxa and environmental variables (López-Sáez \& al., 2015). Correspondence analysis (CA) was used as a unimodal interpretation method because a previously applied principal component analysis (PCA) pointed to a unimodal response of pollen types (variables) instead of lineal responses of taxa (Ter Braak \& Prentice, 1988). We applied a square-root transformation to the pollen percentages to ensure that minor but potentially important pollen taxa would affect the results (Austin, 2013). Graphics of the ordination biplots were made by using CorelDraw. To extract more information from the modern pollen record, supplementary (passive) environmental gradients in the ordination project were included (Table 1).

We calculated Pearson's correlation coefficients between the percentages of palynomorph taxa in each sample and the environmental variables, allowing us to identify anomalous or outlier observations and to analyze the relationships between the pollen spectra and the passive variables. We included a total of 49 taxa to calculate Pearson's correla- tion coefficients, considering only those samples in which the percentages of these taxa are $>0$. Pollen-variable relationships are discussed only for pollen types and samples with significant correlation coefficients ( $r$ value above $0.25, p$ value $<0.05)$ and for those with greater ecological relevance.

\section{Plant Specimens identification-Nomenclature}

Plant specimens taxonomic identification was made by using the following floras: Tutin $\&$ al. (1964-1993), Strid (1986), and Strid \& Tan (1991, 1997, 2002). Taxonomic nomenclature and authorities follow Dimopoulos \& al. (2013).

Syntaxonomical scheme and syntaxa name are after the works of Bergmeier \& Dimopoulos (2001) and Košir \& al. (2008)

\section{Results}

The pollen and non-pollen palynomorph percentage data of the surface samples are summarized in two pollen diagrams (Figures 3 and 4). A total of 90 pollen and spore taxa were identified during the analysis and counts of the 24 surface samples collected.

Figure 4. Percentage pollen diagram for herbs and non-pollen palynomorphs of the 24 surface samples on the Mount Paggeo.

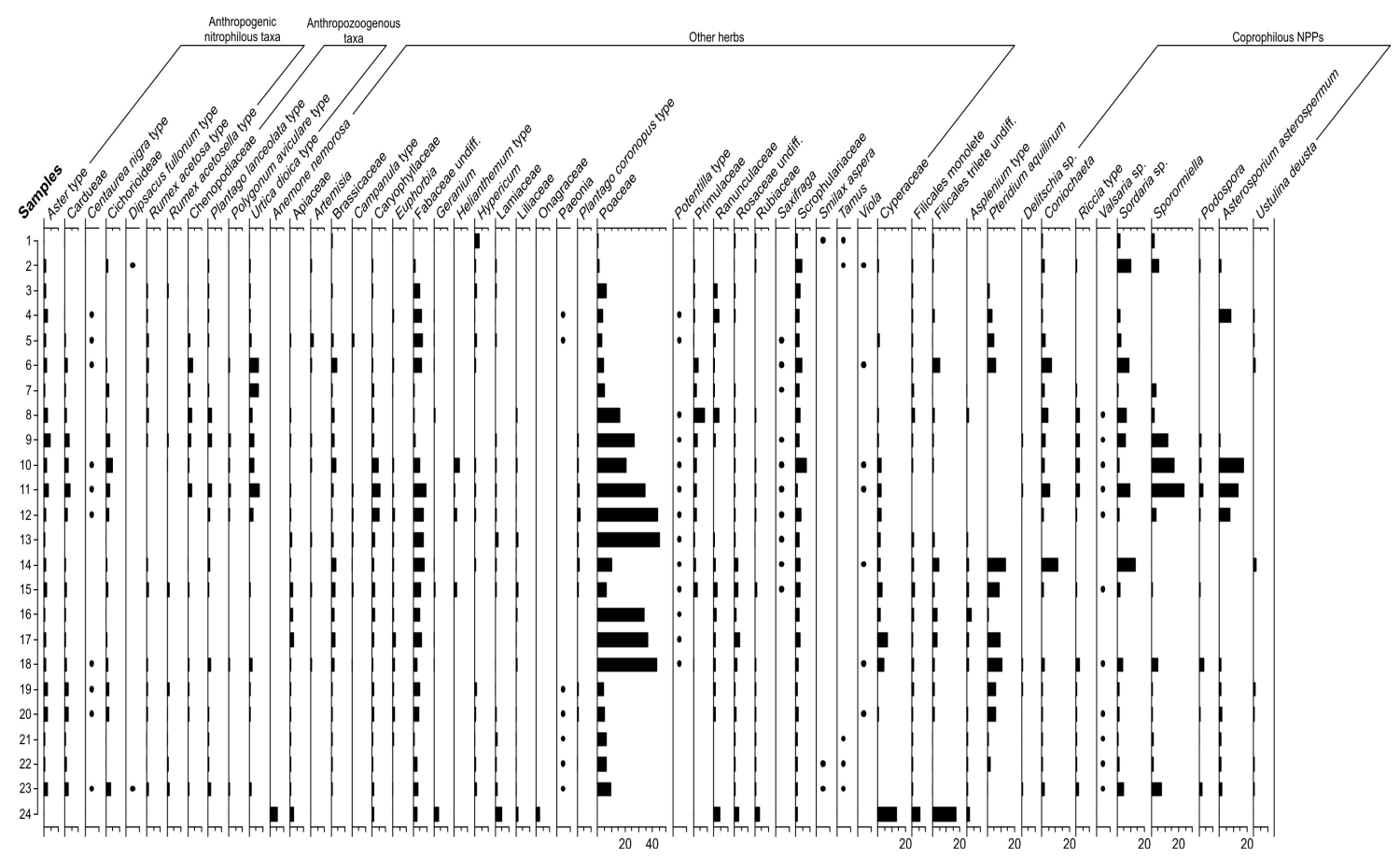


The cluster analysis of the 24 modern pollen rain samples shows five main clusters (Figure 5), demonstrating a clear discrimination between pseudomaquis communities (cluster E; samples 1, 2, 21, 22 and 23) and other clusters. Cluster A (samples 3, 4, 19 and 20) represents thermophilous beech forests, while cluster B includes four samples $(5,6,14$ and 15) from acidophilous beech forests and one ravine forests (sample 24). The high dis- tance value for sample 7 (cluster C), relative to the two clusters above, as well as to each other, set it apart as an individual analytical outlier related to a Pinus sylvestris forest plantation. Finally, cluster D incorporated nine samples with low levels of clustering consistent with a grouping of calcicolous beech forests (samples 8, 9, 13, 16, 17 and 18) and subalpine calcareous grasslands (samples 10, 11 and 12).

Figure 5. Hierarchical cluster analysis (HCA) dendrogram of the 24 modern pollen spectra.

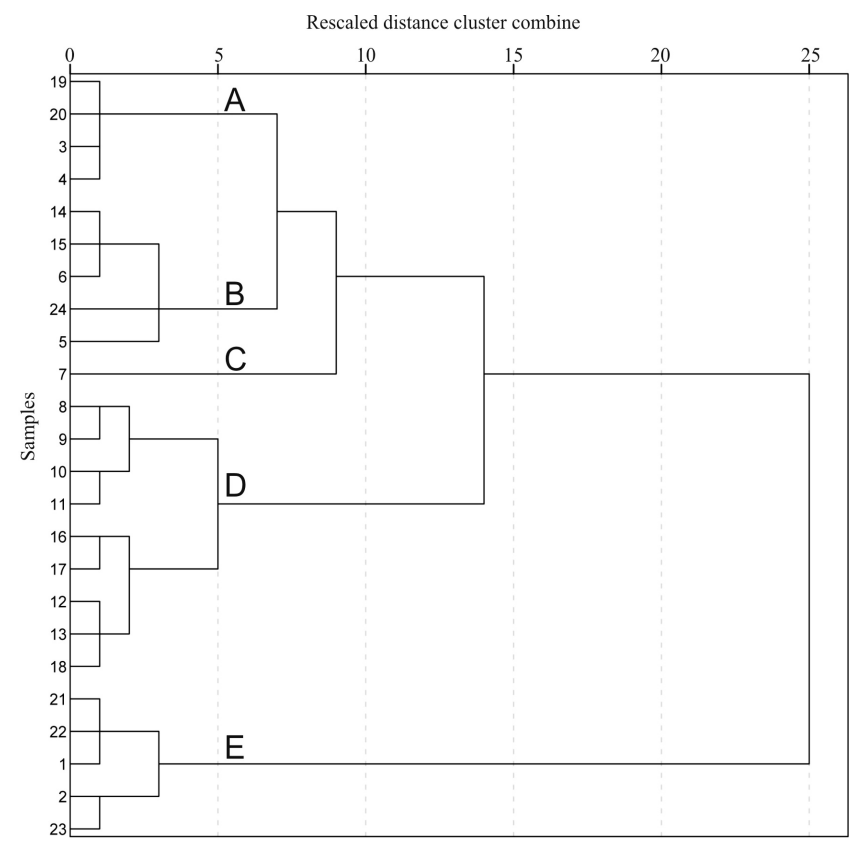

Figure 6. Hierarchical cluster analysis (HCA) dendrogram of pollen taxa.

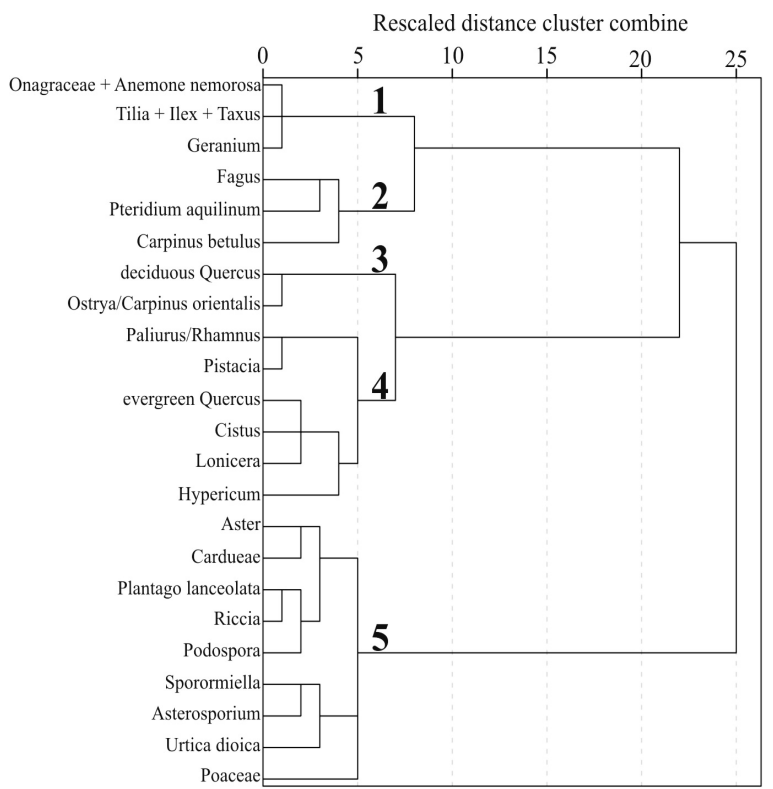


Cluster analysis of the 23 main pollen and non-pollen palynomorph types utilized the pollen data standardized as Z-scores. The results show also five main clusters (Figure $6)$. The two pollen types displaying the greatest similarity, Anemone nemorosa and Onagraceae, cluster with Geranium, Tilia, Ilex and Taxus (cluster 1) and are interpreted as the understorey of ravine forests. A second cluster (cluster 2) consists of Fagus, Pteridium aquilinum and Carpinus betulus, representing acidophilous beech forests, while cluster 3 comprises deciduous Quercus and Ostryal Carpinus orientalis pollen types as the best representatives of thermophilous beech forests. A fourth cluster (cluster 4) includes tightly clustered Paliurus/Rhamnus and Pistacia pollen, plus evergreen Quercus, Cistus, Lonicera and Hypericum clustered at greater distance, reflecting a low elevation group of taxa found in pseudomaquis type vegetation. Finally, cluster 5 incorporated five pollen types (Aster, Cardueae, Plantago lanceolata, Urtica dioica, Poaceae) and four coprophilous non-pollen palynomorphs (Riccia, Podospora, Sporormiella, Asterosporium) with intermediate levels of clustering (based on their rescaled distance values) consistent with a grouping of disturbance taxa.

Figure 7 a shows the results of the CA, displaying the analyzed samples in a biplot of the first two axes accounting for $40.5 \%$ of the total variance. The first axis (accounting for $22.5 \%$ of the total variance) roughly separated samples collected in low-lying $(<910 \mathrm{~m}$ asl) and thermophilic communities, situated on the positive side, from samples taken at higher altitudes, on the negative side. However, two forest samples were situated in the negative side thus disrupting the pattern. These samples were from open calcicolous and moderately grazed beech forests (sample 18, $880 \mathrm{~m}$ asl) and ravine forests on northeastern facing slopes (sample 24, $605 \mathrm{~m}$ asl). In general, samples from acidophilous, ravine and calcicolous beech forests and subalpine calcareous grasslands were placed at the negative side of the axis 1 , while samples from pseudomaquis communities and thermophilous beech forests were mostly at the positive part. Samples 8 and 9 ( 1600 m asl) from calcicolous beech forests lie besides the subalpine calcareous grasslands samples, situated at the negative side of axis 1 . The Pearson product-moment correlation coefficient between altitude and the scores of axis 1 is $r=-0.654$, which is significant at $p<0.03$. On the second CA axis, samples from grazed environments (grazing pressure scale from 2 to 4 ; Table 1) are located on the negative side of axis 2. This axis explains $18 \%$ of the total variance and is most highly negative correlated with grazing pressure $(r=-0.779$ at $p<0.04)$ and positively with tree cover $(r=-0.575$ at $p<0.03)$.

Figure 7. Ordination biplots of the first two correspondence analysis (CA) axes: (a) biplot of the 24 pollen samples and three explanatory variables (see Table 1) passivelly projected into the CA diagram; (b) biplot of the main pollen and non-pollen palynomorph taxa (taxa positioned very close to the origin are not displayed).

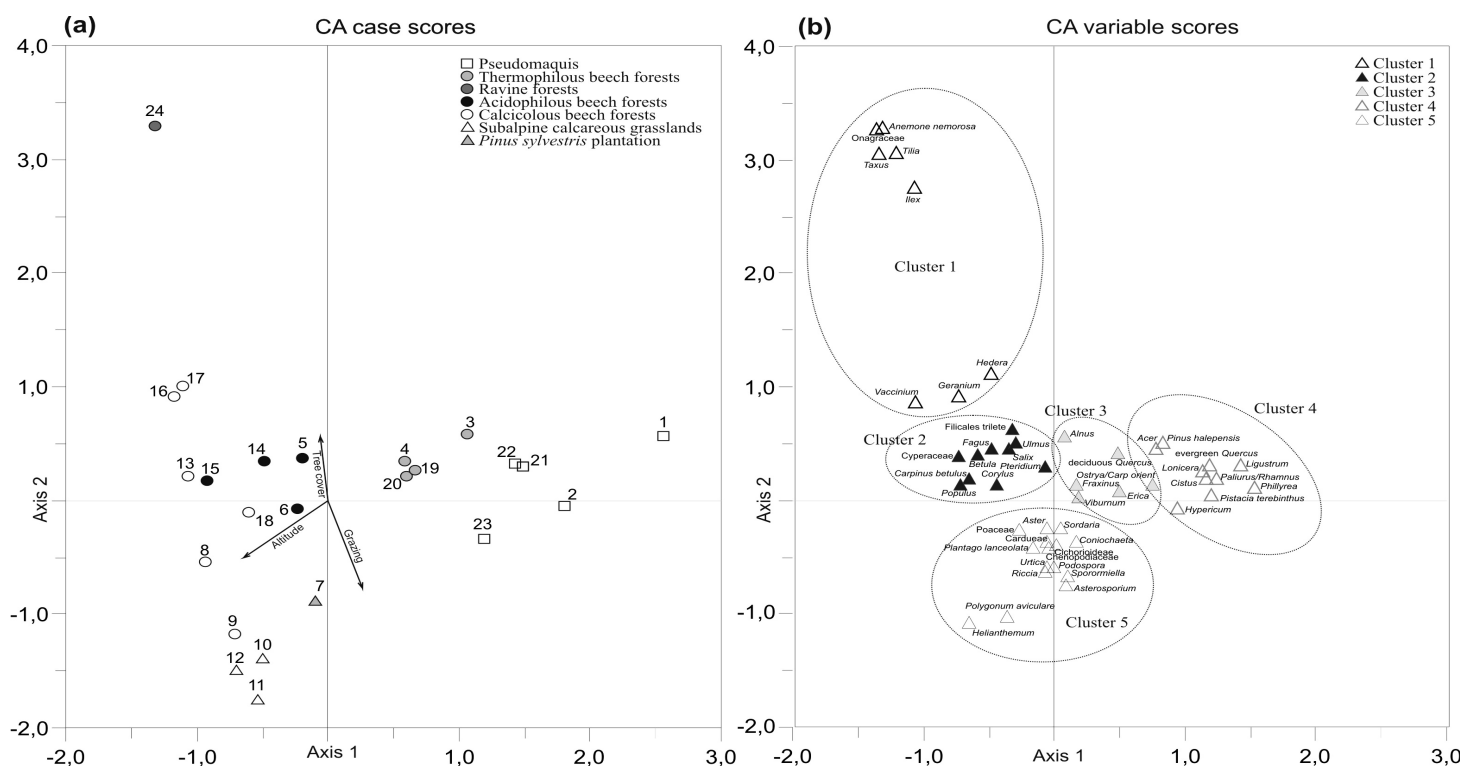


Figure $7 \mathrm{~b}$ shows the distribution of the pollen and non-pollen palynomorph morphotypes along the first two CA axes. Axis 1 separated taxa related to clusters 3 and 4 of the HCA (Figure 6), situated at the positive side, representing thermophilous beech forests and pseudomaquis type vegetation respectively, from the clusters 1 and 2 related with ravine and acidophilous beech forests, which are situated at the negative half. Anthropogenic pollen taxa (Aster, Cardueae, Plantago lanceolata, Polygonum aviculare and Urtica dioica) and Poaceae match showing negative values, while coprophilous fungi are grouped at the positive side. Axis 2 clearly separates anthropogenic and non-pollen palynomorph taxa related to grazing activities (cluster 5), situated on the negative side, from other related to forest communities (clusters 1 to 4), which are located at the positive half.

\section{Discussion}

\section{Gradients and pollen data}

All the classification and ordination analyses show that major patterns of variation in the pollen assemblages were related to altitude and open land versus wooded areas. These gradients are usually identified as the dominant factors by numerical analyses in most modern pollen studies, and our results from the Mount Paggeo thus agree with previous studies carried out in mountain environments of the Mediterranean (e.g. Court-Picon \& al., 2006; López-Sáez \& al., 2013, 2015).

In mountain areas, like Mount Paggeo, altitude is intimately linked to keystone climatic parameters suchs as annual average temperature and total precipitation. In the studied transect, the correlation between samples scores along the first CA axis and altitude is very remarkable (Figure 7a) and statistically significant $(r=-0.654, p<0.03)$. Therefore, altitude may explain the altitudinal pollen and nonpollen palynomorph distribution, but other independent factors should be invoked to fully account for the observed trends. Obviously, they must be related to the variability of temperature and precipitation along the altitudinal transect studied.

Regarding the whole dispersion of the samples, the first axis corresponds to an altitudinal gradient and hence to a temperature one, with a contrast from bottom to top between lower altitude and high mountain plant communities of the Mount Paggeo. In fact, those plant communities that develop at lower altitudes in warmer and less moist conditions are those that are represented on the positive side of CA axis 1 , in which pseudomaquis samples have higher positive loadings than thermophilous beech forest samples. This gradient is more pronounced along the south-eastern slope of the massif, with samples 1 and 2 showing the highest values on this axis. On the contrary, those samples located at higher altitudes and thus supporting gradually cooler and wetter weather conditions are located on the negative side of CA axis 1, particularly those from subalpine calcareous grasslands.

Cluster E of the HCA (Figure 5) represents pseudomaquis communities of mixed deciduous and shrubland formations occurring as a result of degradation of deciduous forests in Greece. It consists of rather tall shrubs, usually dense, with a poor understory of herbs. In Mount Paggeo these formations are dominated by Quercus coccifera as well as other trees and bush elements such as Acer monspessulanum, Carpinus orientalis, Fraxinus ornus, Juniperus oxycedrus, Ostrya carpinifolia, Paliurus spinachristi, Phillyrea latifolia, Pistacia terebinthus and Rhamnus alaternus, growing usually in dry and poor soils at low elevations.

Samples from cluster E $(1,2,21,22,23)$ are characterized by noticeable percentages of evergreen Quercus (> 30\%) and Paliurus /Rhamnus (3-12\%), and significant frequencies of Acer, Ostrya/Carpinus orientalis, deciduous Quercus, Cytisus, Juniperus, Phillyrea, Pistacia terebinthus, Tamus and Smilax aspera (Figures 3 and 4). These pollen taxa also characterized the cluster 4 of the HCA performed on pollen taxa (Figure 6) and they are located on the positive side of CA axis 1 (Figure 7b). Other herbaceous taxa from pseudomaquis samples include moderate amounts of nitrophilous elements suchs as Aster, Cardueae, Cichorioideae, Dipsacus fullonum, Rumex acetosella, Plantago lanceolata and Urtica dioica, as well as spores of some coprophilous non-pollen palynomorphs such as Coniochaeta, Riccia, Sordaria (maximum of 11\%) and Sporormiella (Figure 4). They represent the cluster 5 of the HCA (Figure 6) related to anthropogenic and grazed environments (López-Sáez \& López-Merino, 2007). These morphotypes are located on the negative side of CA axis 2 and are equally representative 
of subalpine calcareous grazed pastures (Figure $7 b$ ). The correlation between samples from grazed environments and grazing pressure is relatively high in CA axis 2 (Figure 7a) and statistically significant $(r=-0.779, p<0.04)$.

For the Quercus coccifera pseudomaquis communities there is no accepted syntaxonomy in Greece (Dimopoulos \& al., 2012). The pure stands of Quercus coccifera, mainly those without a significant cover of Carpinus orientalis, have been included in the Quercetum cocciferae community (Dafis, 1975), although this classification is rather old. According to Tsiourlis \& al. (2009), the association existing in the wider area of Mount Paggeo is the Querco cocciferae-Pistacietosum lentisci, but this assignment is based on a low number of relevés so it likely does not correspond to the communities in the study area.

CA axis 2 may also represent a physiognomic gradient in the vegetation related to the decrease in the percentage cover of trees from bottom to top (Table 1), as it separates samples from forests (positive side) and those from open woodlands and subalpine calcareous grasslands (European Habitat 6170), on the negative side (samples 10, 11 and 12). The correlation between samples and tree cover is high in CA axis 2 (Figure 7a) and statistically significant $(r=-0.575, p<0.03)$.

\section{Characterization of Fagus sylvatica forest communities by pollen assemblages}

As a result of multivariate analyses (HCA and $\mathrm{CA}$ ), four beech related forest habitat types, according to the 92/43/ECC Directive, can be differentiated in the Mount Paggeo in relation to their pollen assemblages: ravine, thermophilous, acidophilous and calcicolous beech forests. Our results coincide with those obtained by Gamisans \& Hebrard (1980), Bergmeier \& Dimopoulos (1999, 2001), Tsiripidis \& al. (2005a, 2005b, 2007a, 2007b) and Tzonev \& al. (2006), who also differentiate four types of beech forests in north-eastern Greece and Bulgaria from numerical analyses performed with relevés.

As previously shown, the arrangement of samples along CA axis 1 follows an altitudinal like trend with some exceptions, notably the presence of samples from ravine forests (sample 24) on the negative side of CA axis 1 (Figure 7a), indicating that this axis may represent not only elevation but also other factors.
Ravine forests (European Habitat 9180) belong to the Tilio-Acerion alliance and the Ostryo carpinifoliae-Tilienion platyphylli suballiance in Greece, although no associations have been distinguished in northern Greece within this suballiance (Košir \& al., 2008). On the north-eastern part of Mount Paggeo, an impressive gorge is formed with an elevation range from 400 to $1600 \mathrm{~m}$ asl (Figure 2). This gorge is mainly covered by the European habitat type 9180, in which beech codominates with other moist-demanding species. This vegetation represents rare and relict plant communities of high conservation value that host private haplotypes of beech (Papageorgiou \& al., 2008, 2014; Hatziskakis $\&$ al., 2009). Floristically these forests are characterized by the presence of Acer platanoides, Ilex aquifolium, Taxus baccata, Tilia platyphyllos, Hedera helix, Anemone nemorosa, Cardamine bulbifera, Galium odoratum and Geranium robertianum among others, as well as a significant coverage of ferns (Asplenium scolopendrium, Athyrium filix-femina, Polystichum ssp.). As no associations or communities in ravine forests of northeast Greece have been described before, we name provisionally this vegetation type as Taxus baccata-Fagus sylvatica community. The former species is that differentiating this vegetation type from other beech forest vegetation types in the wider area, while the latter comprise the dominant species of this vegetation type.

Sample 24 from ravine forests is placed in the cluster B together with acidophilous forests (Figure 5) due to their palynological affinities (Figures 3 and 4). However, specific pollen taxa of these ravine forests (Anemone nemorosa 5.7\%, Onagraceae $2.6 \%$, Geranium $3.6 \%$, Tilia $8.9 \%$, Ilex $2.3 \%$ and Taxus $3.3 \%$ ) individualize the cluster 1 of the HCA analysis carried out only with pollen taxa (Figure 6), which is located on the negative side of CA axis 1 (Figure $7 b$ ). Both types of forests cannot be distinguished from the cluster analysis for several reasons: i) both grow on siliceous substrates and host acidophilous species; ii) in both vegetation types beech dominates, while the taxa differentiating ravine forests (e.g. Taxus baccata, Tilia ssp., Acer ssp., Ulmus glabra) have low cover and are poor pollen producers (Abel-Schaad \& al., 2014); and, iii) only one modern pollen sample has been taken in ravine forests. In short, our data do not 
allow us to assign the sample 24 to the plant communities described by Schreiber (1998) from inventories conducted near the treeline of Mount Paggeo in sites with very special topographical characteristics (e.g. small rocky depressions) where mesophilous species may develop. The affinities between their pollen assemblages and their joint position on the cluster B (Figure 5), lead us to propose that the sample 24 probably represent a mesophilous variant of the acidophilous beech forests. New relevés that are made in the future along the large gorge of the Paggeo on its northeast slope will probably refine this situation.

Cluster A of the HCA (Figure 5) represents thermophilous beech forests growing on acidic soils, mainly on gneiss-schist substrates, at the low elevations of the south-eastern and northwestern slopes of the Mount Paggeo (Figure 2, Table 1), corresponding to the Luzula forsteriFagus sylvatica community ("Quercus frainetto woods", European Habitat 9280), which is characterized by the occurrence of both Fagetalia and Quercetalia pubescentis species in its floristic composition (Tsiripidis \& al., 2005a, 2005b, 2007a, 2007b). The overall appearance is that of mixed beech forests with Quercus frainetto and Q. petraea subsp. polycarpa (Tsiripidis \& al., 2007a). The most representative palynomorph taxa of these forests are those included in cluster 3 such as deciduous Quercus and Ostrya/Carpinus orientalis (Figures 6 and $7 \mathrm{~b}$ ). The pollen diagram clearly indicates the importance of the above mentioned pollen taxa (deciduous Quercus 30$32 \%$, Ostrya/Carpinus orientalis $1.3-5.7 \%$ ) and the sporadic percentages of Acer, Lonicera, Prunus/Rosa/Rubus, Ranunculaceae and Viola (Figures 3 and 4). Samples of the cluster A (3, 4, 19 and 20) in the CA plot are arranged close to the relevant pollen indicator taxa (Figure 7) and therefore represent quite well the observed vegetation conditions. These four samples are grouped on the positive side of CA axis 1 representing low-lying and thermophilous beech forests. However, sample 3 appears relatively far from the other with higher positive scores on both CA axes (Figure 7a), since no evidence of grazing (coprophilous NPPs) appears in its pollen assemblage (Figure 4).

Although cluster B of the HCA (Figure 5) includes sample 24 from ravine forests, the remaining samples $(5,6,14$ and 15) represent acidophilous beech forests classified as the Calamagrostis arundinacea-Fagus sylvatica community by Tsiripidis \& al. (2007b), corresponding to the European Habitat 9110 ("Luzulo-Fagetum beech forests"). These forests are developed between 1000 and 1200 $\mathrm{m}$ asl on gneiss or schists (Figure 2, Table 1). Their overall appearance on Mount Paggeo is a pure or mixed beech forest with Abies x borisii-regis and Betula pendula. The occurrence of these acidophilous beech forests can be recognized in the pollen diagrams (Figures 3 and 4 ) by relatively high percentages of Betula (35\% in sample 5), Abies ( 1\%), Castanea (1-3\%), Carpinus betulus (1-2\%), Fabaceae (6-9\%) and Pteridium aquilinum (5-14\%), although Fagus (6-20\%) is the dominant pollen type in the dataset characterizing cluster 2 of the HCA (Figure 6). These pollen taxa are positioned with negative values on CA axis 1, close to samples from acidophilous forests (Figure 7).

Finally, cluster D includes samples of both calcicolous beech forests $(8,9,13,16,17$ and $18)$ and subalpine calcareous grasslands (samples 10,11 and 12) with very low levels of clustering and little differentiation between the two types of vegetation (Figure 5). These facts are particularly evident in the grouping of samples 8, 9 and 18 on the one hand (calcicolous beech forests) and 10,11 and 12 on the other (subalpine calcareous grasslands), located both on the negative side of CA axis 2 (Figure 7a), due to high levels in grazing pressure (Table 1). All these samples are characterized by high percentages of coprophilous NPPs, particularly Delitschia, Coniochaeta, Riccia, Sordaria, Sporormiella, Podospora and Anterosporium asterospermum (Figure 4), located also on the negative side of CA axis 2 (Figure $7 \mathrm{~b}$ ). Samples 8 and 9 are relatively close to the sample 7 on the negative side of CA axis 2 (Figure 7a) due to their high percentage of Pinus sylvestris/nigra (10-19\%) and their geographic proximity (Figure 2). Meanwhile, sample 13 has similar scores to samples 10, 11 and 12 (subalpine calcareous grasslands) on the negative side of the $\mathrm{CA}$ axis 1 , although it is clearly separated from samples 8, 9 and 18 (calcicolous beech forests) along CA axis 2. This is because sample 13 was collected in the ecotone between beech forests and subalpine grasslands in an area without grazing pressure (Figure 2, Table 1).

Samples 8, 9, 13, 16, 17 and 18 represent the "Medio-European limestone beech forests 
of the Cephalanthero-Fagion" (9150) habitat type, calcicolous beech forests classified as the Brachypodium pinnatum-Fagus sylvatica community by Tsiripidis \& al. (2007b). These forests are developed between 950 and $1600 \mathrm{~m}$ asl on calcareous substrates, mainly marbles (Figure 2, Table 1). Pollen assemblages from unaltered calcicolous beech forests (samples 16 and 17) are characterized by large numbers of tree taxa such as Corylus (9-10\%), Fagus (20-27\%), Carpinus betulus and Fraxinus, and high values of Poaceae (34-37\%) (Figures 3 and 4). These two samples are located relatively close to samples 14 and 15 (acidophilous beech forests), on the negative side of CA axis 1 and on the positive half of CA axis 2 (Figure 7a), due to their geographical proximity on the north-western slope of Mount Paggeo (Figure 2). This northwest exposed area is characterized, from a geological point of view, by alternating bends of marbles and gneisses (Eliopoulos, 2000; Eleftheriadis \& Koroneos, 2003) populated with dense acidophilous and calcicolous beech forests. In fact, some authors have included relevés carried out on acid soils within these from calcicolous beech forests, because in the northwest of Mount Paggeo both forests share many floristic affinities (Tsiripidis \& al., 2007a, 2007b).

\section{Conclusions}

Our study provides a set of modern pollen data spectra which contributes to improve the lack of data from north-eastern Greece. Our results clearly demonstrate that it is possible to obtain distinct pollen markers for the Fagus sylvatica forests of the Mount Paggeo. These distinctions are related to specific climatic or geographic gradients, as well as with grazing activities linked to human pressure on mountain ecosystems.

The HCA classification and the CA ordination of the 24 samples show two main gradients in the study area. The grazing pressure gradient is reflected by the second CA axis and contributes to the first division of the HCA classification, which separates disturbance taxa from forest ones. CA axis 2 may also represent a physiognomic gradient related to the tree cover, between grasslands and forested areas. The altitudinal and temperature gradient is reflected by the first $\mathrm{CA}$ axis, which separates pseudomaquis vegetation and thermophilous beech forests from acidophilous and calcicolous ones and subalpine calcareous grasslands. This second gradient is stronger along the south-eastern slopes of the Mount Paggeo probably due to the lower elevation and the proximity of the Mediterranean Sea. Ravine forests were not possible to be distinguished from acidophilous beech ones possibly because of the absence of adequate pollen and vegetation data.

\section{Syntaxonomical scheme of beech forests in the Mount Paggeo}

QuerCo Roboris-FaGETEA SYLVATICAE Br.-Bl. \& Vlieger in Vlieger 1937

Fagetalia sylvaticae PawBowski in PawBowski, SokoBowski \& Wallisch 1928 Fagion sylvaticae Luquet 1926

Doronico columnae-Fagenion moesiacae Dzwonko, Loster, Dubiel \& Drenkovski 1999

1. Brachypodium pinnatumFagus sylvatica community

2. Calamagrostis arundinaceaFagus sylvatica community

3. Luzula forsteri-Fagus sylvatica community

Tilio platyphylli-Acerion pseudoplatani Klika 1955

Ostryo carpinifoliae-Tilienion platyphylli Košir, Carni \& Di Pietro 2008 4. Taxus baccata-Fagus sylvatica community 


\section{Bibliography}

Abel-Schaad, D., Pulido, F.J., López-Sáez, J.A., Alba-Sánchez, F., Nieto-Lugilde, D., Franco-Múgica, F., Pérez-Díaz, S., Ruiz-Zapata, M.B., Gil-García, M.J. \& Dorado Valiño, M. 2014. Persistence of tree relicts through the Holocene in the Spanish Central System. Lazaroa 35: 107-131.

Austin, M.P. 2013. Inconsistencies between theory and methodology: a recurrent problem in ordination studies. J. Veg. Sci. 24: 251-268.

Balafoutis, C. 1977. Beitrag zum Studium des Klimas von Mazedonien und WestThrazien. PhD diss.

Bergmeier, E. \& Dimopoulos, P. 1999. Classification of Greek Fagus woodlands: a preliminary survey. Ann. Bot. (Rome) 57: 91-104.

Bergmeier, E. \& Dimopoulos, P. 2001. Fagus sylvatica forest vegetation in Greece: Syntaxonomy and gradient analysis. J. Veg. Sci. 12: 109-126.

Bergmeier, E. \& Dimopoulos, P. 2008. Identifying plant communities of thermophilous deciduous forest in Greece: Species composition, distribution, ecology and syntaxonomy. Plant Biosyst. 142: 228-254.

Blackmore, S., Steinmann, J.A.J., Hoen, P.P. \& Punt, W. 2003. The Northwest European Pollen Flora, 65. Betulaceae and Corylaceae. Rev. Palaeobot. Palynol. 123: 71-98.

Comps, B., Gömöry, D., Letouzey, J., Thiebaut, B. \& Petit, R.J. 2001. Diverging trends between heterozygosity and allelic richness during postglacial colonization in the European beech. Genetics 157: 389-397.

Court-Picon, M., Buttler, A. \& de Beaulieu, J.L. 2006. Modern pollen/ vegetation/land-use relationships in mountain environments: an example from the Champsaur valley (French Alps). Veget. Hist. Archaeobot. 15: 151-168.

Dafis, S. 1975. Vegetationsgliederung Griechenlands. In: Dafis, S. \& Landolt, E. (Eds.). Zur Vegetation and Flora Griechenlands. Veröff. Geobot. 55. Pp. 23-36. Geobot. Inst. Stift. Rübel. Zürich.

Dafis, S., Papastergiadou, E., Lazaridou, M. \& Tsiafouli, M. 2001. Technical guide for the identification, description and mapping of habitat types in Greece. Greek Centre of Biotopes-Wetlands. Athens.

Demesure, B., Comps, B. \& Petit, R.J. 1996. Chloroplast DNA phylogeography of the common beech (Fagus sylvatica L.) in Europe. Evolution 50: 2515-2520.

Denk, T. 2003. Phylogeny of Fagus L. (Fagaceae) based on morphological data. Plant Syst. Evol. 240: 5581.

Denk, T., Grimm, G., Stögerer, K., Langer, M. \& Hemleben, V. 2002. The evolutionary history of Fagus in western Eurasia: Evidence from genes, morphology and the fossil record. Plant Syst. Evol. 232: 213236.

Dimopoulos, P., Raus, T., Bergmeier, E., Constantinidis, T., Iatrou, G., Kokkini, S., Strid, A. \& Tzanoudakis, D. 2013. Vascular plants of Greece: an annotated checklist. Bot. Gart. Bot. Mus. BerlinDahlem, Freie Univ. Berlin \& Hellenic Bot. Soc., Berlin \& Athens.

Dimopoulos, P., Tsiripidis, I., Bergmeier, E., Fotiadis, G., Theodoropoulos, K., Raus, T., Panitsa, M., Kallimanis, A.S., Sýkora, K.V. \& Mucina, L. 2012. Towards the Hellenic National Vegetation Database: VegHellas. Plant Sociol. 49: 81-87.

Eleftheriadis, G. \& Koroneos, A. 2003. Geochemistry and petrogenesis of post-collision Pangeon granitoids in Central Macedonia, Northern Greece. Chem. Erde-Geochem. 63: 364-389.

Eliopoulos, D.G. 2000. Geochemistry and origin of the asimotrypes carbonate-hosted mesothermal gold deposit, Pangeon Mountain, North Greece. PhD diss. Univ. Southampton, Southampton.

Faegri, K. \& Iversen, J. 1989. Textbook of Pollen Analysis. Wiley, Chichester.

Filipova-Marinova, M. 1995. The late Quaternary history of the genus Fagus L. in Bulgaria. In: Bozilova, E. \& Tonkov, S. (Eds.). Advances in Holocene paleoecology in Bulgaria. Pp. 84-95. Pensoft Publ., Sophia.

Gailing, O. \& von Wuehlisch, G. 2004. Nuclear markers (APLFs) and chloroplast microsatellites differ between Fagus sylvatica and Fagus orientalis. Silvae Genet. 53: 105-110.

Gamisans, J. \& Hebrard, J.P. 1980. À propos de la végétation des forêts en Grèce du nord-est (Macédoine orientale et Thrace continentale). Doc. Phytosoc. 5: 243-289.

Georghiou, K. \& Delipetrou, P. 2010. Patterns and traits of the endemic plants of Greece. Bot. J. Linn. Soc. 162: $130-422$.

Gerasimidis, A., Panajiotidis, S., Hicks, S. \& Athanasiadis, N. 2006. An eight-year record of pollen deposition in the Pieria Mountains (N. Greece) and its significance for interpreting fossil pollen assemblages. Rev. Palaeobot. Palynol. 141: 231-243. 
Glais, A., Lezpez, L., Davidson, R., López-Sáez, J.A. \& Birée, L. 2016a. 3000 ans de détritisme en Grèce du Nord: entre fluctuations climatiques et anthropisation des zones humides. Géomorphologie 22: 5576.

Glais, A., López-Sáez, J.A., Lespez, L. \& Davidson, R. 2016b. Climate and human-environment relationships on the edge of the Tenaghi-Philippon marsh (Northern Greece) during the Neolithization process. Quat. Int. 403: 237-250.

Gömöry, D., Paule, L., Brus, R., Zhelev, P., Tomović, Z. \& Gračan, J. 1999. Genetic differentiation and phylogeny of beech on the Balkan Peninsula. J. Evol. Biol. 12: 746-754.

Govaerts, R., Andrews, S., Coombes, A., Gilbert, M., Hunt, D., Nixon, K. \& Thomas, M. 2013. World checklist of Fagaceae. R. Bot. Gardens, Kew.

Grimm, E.C. 1992. Tilia version 2. Illinois State Museum. Res. Coll. Center, Springfield.

Hatziskakis, S., Papageorgiou, A.C., Gailing, O. \& Finkeldey, R. 2009. High chloroplast haplotype diversity in Greek populations of beech (Fagus sylvatica L.). Plant Biol. 11: 425-433.

Hatzizkakis, S., Tsiripidis, I. \& Papageorgiou, A.C. 2011. Leaf morphological variation in beech (Fagus sylvatica L.) populations in Greece and its relation to their post-glacial origin. Bot. J. Linn. Soc. 165: 422-436.

Hazler, K., Comps, B., Šugar, I., Melovsky, L., Tashev, A. \& Gračan, J. 1997. Genetic structure of Fagus sylvatica L. populations in Southeastern Europe. Silvae Genet. 46: 229-236.

Hewitt, G.M. 1996. Some genetic consequences of ice ages, and their role in divergence and speciation. Biol. J. Linn. Soc. 58: 247-276.

Hicks, S., Tinsley, H., Huusko, A., Jensen, C., Hättestrand, M., Gerasimidis, A. \& Kvavandze, E. 2001. Some comments on spatial variation in arboreal pollen deposition: first records from the Pollen Monitoring Programme (PMP). Rev. Palaebot. Palynol. 117: 183-194.

Huntley, B. \& Birks, H.J. 1983. An atlas of past and present pollen maps for Europe, 0-13000 years ago. Cambridge Univ. Press, Cambridge.

Karagiannakidou, V., Dimopoulos, P. \& Papademetriou, K. 2001. Phytosociological researches on the montane and high-altitude grasslands of North Eastern Greece: Mount Pangeon. Fitosociologia 38: 2554.

Košir, P., Carni, A. \& Di Pietro, R. 2008. Classification and phytogeographical differentiation of broadleaved ravine forests in southeastern Europe. J. Veg. Sci. 19: 331-342.

Lespez, L., Glais, A., López-Sáez, J.A., Le Drezen, Y., Tsirtsoni, Z., Davidson, R., Birée, L. \& Malamidou, D. 2016. Middle Holocene rapid environmental changes and human adaptation in Greece. Quat. Res. 85: $227-244$.

López-Merino, L., López-Sáez, J.A., Ruiz-Zapata, M.B. \& Gil-García, M.J. 2008. Reconstructing the history of beech (Fagus sylvatica L.) in the north-western Iberian Range (Spain): From Lateglacial refugia to the Holocene anthropic-induced forests. Rev. Palaebot. Palynol. 152: 58-65.

López-Sáez, J.A., Alba-Sánchez, F., López-Merino, L. \& Pérez-Díaz, S. 2010. Modern pollen analysis: a reliable tool for discriminating Quercus rotundifolia communities in Central Spain. Phytocoenologia 40: 57-72.

López-Sáez, J.A., Alba-Sánchez, F., Sánchez-Mata, D., Abel-Schaad, D., Gavilán, R.G. \& Pérez-Díaz, S. 2015. A palynological approach to the study of Quercus pyrenaica forest communities in the Spanish Central System. Phytocoenologia 45: 107-124.

López-Sáez, J.A. \& López-Merino, L. 2007. Coprophilous fungi as a source of information of anthropic activities during the Prehistory in the Amblés Valley (Ávila, Spain): the archaeopalynological record. Rev. Esp. Micropal. 39: 103-116.

López-Sáez, J.A., Sánchez-Mata, D., Alba-Sánchez, F., Abel-Schaad, D., Gavilán, R.G. \& Pérez-Díaz, S. 2013. Discrimination of Scots pine forests in the Iberian Central System (Pinus sylvestris var. iberica) by means of pollen analysis. Phytosociological considerations. Lazaroa 34: 191-208.

Magri, D. 2008. Patterns of post-glacial spread and the extend of glacial refugia of European beech (Fagus sylvatica). J. Biogeogr. 35: 450-463.

Magri, D., Vendramin, G.G., Comps, B., Dupanloup, I., Geburek, T., Gömöry, D., Latalowa, M., Litt, T., Paule, L., Roure, J.M., Tantau, I., van der Knaap, W.O., Petit, R.J. \& de Beaulieu, J.L. 2006. A new scenario for the Quaternary history of European beech populations: paleobotanical evidence and genetic consequences. New Phytol. 171: 199-221.

Médail, F. \& Diadema, K. 2009. Glacial refugia influence plant diversity patterns in the Mediterranean Basin. J. Biogeogr. 36: 1333-1345.

Moore, P.D., Webb, J.A. \& Collinson, M.E. 1991. Pollen analysis ( $2^{\text {nd }}$ ed.). Blackwell Scientific Publications. London.

Moulopoulos, C. 1965. The beech woods of Greece. Part 1. The beech species and their distribution in Greece. Epist. Epet. Geopon. Dasol. Shol. Arist. Panepist. Thessalonikis 1965: 1-85. 
Paffetti, D., Vettori, C., Caramelli, D., Vernesi, C., Lari, M., Paganelli, A., Paule, L. \& Giannini, R. 2007. Unexpected presence of Fagus orientalis complex in Italy as inferred from 45,000-year-old DNA pollen samples from Venice lagoon. BMC Evol. Biol. 7 (Suppl. 2): S6.

Papageorgiou, A.C., Tsiripidis, I., Mouratidis, T., Hatziskakis, S., Gailing, O., Eliades, N.G.H., Vidalis, A., Drouzas, A.D. \& Finkeldey, R. 2014. Complex fine-scale phylogeographical patterns in a putative refugial region for Fagus sylvatica (Fagaceae). Bot. J. Linn. Soc. 174: 516-528.

Papageorgiou, A.C., Vidalis, A., Gailing, O., Tsiripidis, I., Hatziskakis, S., Boutsios, S., Galatsidas, S. \& Finkeldey, R. 2008. Genetic variation of beech (Fagus sylvatica L.) in Rodopi (N.E. Greece). Eur. J. Forest Res. 127: 81-88.

Paule, L. 1995. Gene conservation in European beech (Fagus sylvatica L.). For. Genet. 2: 161-170.

Piotti, A., Leonardi, S., Buiteveld, J., Geburek, T., Gerber, S., Kramer, K., Vettori, C. \& Vendramin, G.G. 2012. Comparison of pollen gene flow among four European beech (Fagus sylvatica L.) populations characterized by different management regimes. Heredity 108: 322-331.

Pott, R. 1997. Invasion of beech and establishment of beech forests in Europe. Ann. Bot. (Rome) 55: 2758.

Prentice, I.C. 1985. Pollen representation, source area, and basin size: toward a unified theory of pollen analysis. Quat. Res. 23: 76-86.

Rajendra, K.C., Seifert, S., Prinz, K., Gailing, O. \& Finkeldey, R. 2014. Subtle human impacts on neutral genetic diversity and spatial patterns of genetic variation in European beech (Fagus sylvatica). For. Ecol. Manag. 319: 138-149.

Schreiber, H.J. 1998. Waldgrenznahe Buchenwälder und Grasländer des Falakro und Pangäon in Nordostgriechenland. Syntaxonomie, Struktur und Dynamik. Arb. Inst. Landschaftsökol. Westf. Wilhelms-Univ. Münster 4: 1-171.

Strid, A. (Ed.). 1986. Mountain flora of Greece 1. Cambridge University Press. Cambridge.

Strid, A. \& Tan, K. (Eds.). 1991. Mountain flora of Greece 2. Edinburgh University Press. Edinburgh.

Strid, A. \& Tan, K. (Eds.). 1997, 2002. Flora Hellenica, 2 vols.. Koeltz. Königstein.

Sugita, S. 1994. Pollen representation of vegetation in Quaternary sediments: theory and method in patchy vegetation. J. Ecol. 82: 881-897.

Taberlet, P., Fumangalli, L., Wust-Sausy, A. \& Cosson, J. 1998. Comparative phylogeography and postglacial colonization routes in Europe. Mol. Ecol. 7: 453-464.

Ter Braak, C.J.F. \& Prentice, I.C. 1988. A theory of gradient analysis. Adv. Ecol. Res. 18: 271-317.

Tsiftsis, S., Karagiannakidou, V. \& Tsiripidis, I. 2007. The orchid flora of East Macedonia (NE Greece). J. Eur. Orch. 39: 489-526.

Tsiourlis, G., Konstantinidis, P. \& Xofis, P. 2009. Syntaxonomy and synecology of Quercus coccifera Mediterranean shrublands in Greece. J. Plant. Biol. 52: 433-447.

Tsiripidis, I. \& Athanasiadis, N. 2003. Contribution to the knowledge of the vascular flora of NE Greece: floristic composition of the beech (Fagus sylvatica L.) forests in the Greek Rodopi. Willdenowia 33: 273-298.

Tsiripidis, I., Bergmeier, E. \& Dimopoulos, P. 2007a. Geographical and ecological differentiation in Greek Fagus forest vegetation. J. Veg. Sci. 18: 743-750.

Tsiripidis, I., Fotiadis, G., Karagiannakidou, V. \& Dimitros, B. 2005a. Classification problems of forest vegetation in Greece: Transition from beech to deciduous oak zone. Bot. Chr. 18: 253-268.

Tsiripidis, I., Karagiannakidou, V., Alifragis, D. \& Athanasiadis, N. 2007b. Classification and gradient analysis of the beech forest vegetation of the Southern Rodopi (Northeast Greece). Folia Geobot. 42: 249-270.

Tsiripidis, I., Karagiannakidou, V. \& Athanasiadis, N. 2005b. Ecological and phytogeographical differentiation of beech forests in Greek Rodopi (Northeast Greece). Biologia (Bratislava) 60: 57-67.

Tutin, T.G., Heywood, V.H., Burges, N.A., Moore, D.M., Valentine, D.H., Walters, S.M. \& Webb, D.A. 1964-1993. Flora Europaea, 5 vols. Cambridge University Press. Cambridge.

Tzedakis, C., Emerson, B.C. \& Hewitt, G.M. 2013. Cryptic or mystic? Glacial tree refugia in northern Europe. Trends Ecol. Evol. 28: 696-704.

Tzedakis, P.C., Hooghiemstra, H. \& Pälike, H. 2006. The last 1.35 million years at Tenaghi Philippon: revised chronostratigraphy and long-term vegetation trends. Quat. Sci. Rev. 25: 3416-3430.

Tzedakis, P.C., Lawson, I.T., Frogley, M.R., Hewitt, G.M. \& Preece, R.C. 2002. Buffered tree population changes in a Quaternary refugium: evolutionary implications. Science 297: 2044-2047.

Tzonev, R., Dimitrov, M., Chytrý, M., Roussakova, V., Dimova, D., Gussev, C., Pavlov, D., Vulchev, V., Vitkova, A., Gogoushev, G., Nikolov, I., Borisova, D. \& Ganeva, A. 2006. Beech forest communities in Bulgaria. Phytocoenologia 36: 247-279.

Van Geel, B. 2001. Non-pollen palynomorphs. In: Smol, J.P., Birks, H.J.B. \& Last, W.M. (Eds.). Tracking environmental change using lake sediments, vol. 3: Terrestrial, algal, and siliceous indicators. Pp. 99119. Kluwer. Dordrecht. 
Vettori, C., Paffetti, D., Paule, L. \& Giannini, R. 2004. Identification of the Fagus sylvatica L. and Fagus orientalis Lipsky species and intraspecific variability. For. Genet.10: 223-230.

Vornam, B., Decarli, N. \& Gailing, O. 2004. Spatial distribution of genetic variation in a natural beech stand (Fagus sylvatica L.) based on microsatellite markers. Conserv. Genet. 5: 561-570.

Ward, J.H. 1963. Hierarchical grouping to optimize an objective function. J. Am. Stat. Assoc. 58: 236-244.

Willis, K.J. 1994. The vegetational history of the Balkans. Quat. Sci. Rev. 13: 769-788.

Willis, K.J. \& van Andel, T.H. 2004. Trees or no trees? The environments of central and eastern Europe during the Last Glaciation. Quat. Sci. Rev. 23: 2369-2387. 